\title{
A Comparative Study on Fungal Laccases Immobilized on Chitosan
}

\author{
José Hilton Bernardino de Araújo ${ }^{1 *}$, Vinicius Oliveira Uemura ${ }^{1}$, Flavio Faria de Moraes ${ }^{1}$, \\ Aneli de Melo Barbosa ${ }^{2}$ and Gisella Maria Zanin ${ }^{1}$ \\ ${ }^{1}$ Departamento de Engenharia Química; Universidade Estadual de Maringá; Av. Colombo, 5790; BL D-90; \\ 87020-900; Maringá - PR - Brasil. ${ }^{2}$ Departamento de Biologia; Universidade Estadual de Londrina; Campus \\ Universitário; Rod. Celso Garcia Cid Pr 445, Km 380; 86051-990; Londrina - PR - Brasil
}

\begin{abstract}
The phenoloxidase enzyme laccase from the cultures of the Pleurotus ostreatus and Botryosphaeria sp. and a commercial laccase from Aspergillus sp. were immobilized on chitosan of pharmaceutical degree by adsorption followed by crosslinking. Different immobilization conditions in relation to the granulometry of support and amount of enzymatic laccase extract used were tested, aiming at reaching high enzymatic activity with the immobilized enzyme. Two different substrates, ABTS and DMP, were used for the determination of enzymatic activity. The highest enzymatic activity was obtained when $1.0 \mathrm{mg} / \mathrm{mL}$ of the enzymatic laccase extract from Botryosphaeria sp. was used with $1.0 \mathrm{~g}$ of support (200 mesh). These immobilized enzymes are to be applied to the improvement of white wines by the degradation of undesirable phenolic compounds.
\end{abstract}

Key words: Laccases; immobilization; chitosan

\section{INTRODUCTION}

Laccase (EC 1.10.3.2), an enzyme widely distributed in higher plants, bacteria and fungi, has received particular attention because of its ability to catalyze the oxidation of a wide spectrum of molecules containing an aromatic ring substituted with electron withdrawing groups. Its rather low specificity makes laccase a promising tool in transforming many toxic substituted phenols or even non-phenolic compounds such as polycyclic aromatic hydrocarbons. The reduction of a substrate typically involves the formation of a free cation radical which can further undergo laccasecatalyzed oxidation reactions, generally leading to the formation of quinones from phenols, or nonenzymatic transformation such as hydration or polymerization, forming high molecular weight insoluble components (Jolivat et al.,2000).

Laccase is a widely studied enzyme because of its potential use in several areas such as, food, textile paper and pulp industries. Laccase can be used in bioremediation, beverage processing, ascorbic acid determination, baking, as biosensor and to improve food sensory parameters (Minussi et al., 2002; Gianfreda et al., 1999).

\section{MATERIALS AND METHODS}

\section{Chemicals}

Chitosan from crab shells was obtained from Farmacon Ltda, Maringa, Parana, Brazil. Glutaraldehyde (25\%), 2,2'-azino-bis(3-ethyl-

\footnotetext{
${ }^{*}$ Author for correspondence
} 
benzthiazoline-6-sulfonic acid) (ABTS) and 2,6 dimethoxyphenol (DMP) were purchased from Riedel-de-Haën, Sigma-Aldrich and Across Organic, respectively.

\section{Enzymes}

Laccases from Pleurotus ostreatus (Florida variety), and Botryosphaeria sp. were produced in the Laboratory. Commercial enzyme, Denilite Base 2, produced from Aspergilus sp. was a gift from Novo Nordisk.

\section{Analytical methods}

Laccase activity was assayed with two different substrates, ABTS and DMP. PPO-I is the laccase activity measured with ABTS and PPO-II is the laccase activity determined using DMP as substrate. Typical assays consisted of incubating a mixture containing $0.05 \mathrm{~mL}$ ABTS $(40 \mathrm{mM}$, in water), $0.15 \mathrm{~mL}$ of McIlvaine's citrate-phosphate buffer $(60 \mathrm{mM}, \mathrm{pH} 3.0$ for Botryosphaeria sp. and pH 4.0 for Pleurotus ostreatus and Aspergilus sp.), and enzyme $(0.10 \mathrm{~mL}$, diluted when necessary $)$, in a final volume of $1 \mathrm{~mL}$, at $50^{\circ} \mathrm{C}$ for $5 \mathrm{~min}$, and the absorbance measured at $420 \mathrm{~nm}$ ( $\varepsilon: 36000 \mathrm{~mol}^{-1}$ $\mathrm{cm}^{-1}$ ).

DMP oxidation was performed with $0.1 \mathrm{mM}$ DMP in McIlvaine's citrate-phosphate buffer $(60 \mathrm{mM}$, $\mathrm{pH} 6.5$ for Botryosphaeria sp. and $\mathrm{pH} 5.0$ for Pleurotus ostreatus and Aspergilus sp.), at $45^{\circ} \mathrm{C}$ for $5 \mathrm{~min}$, and monitoring the increase in $\mathrm{A}_{468}(\varepsilon$ : $10000 \mathrm{~mol}^{-1} \mathrm{~cm}^{-1}$ ).

The number of units of enzyme activity in a $\mathrm{mL}$ of enzyme solution corresponds to the number of $\mu$ mol of ABTS or DMP oxidized per min and $\mathrm{mL}$ of enzyme solution, or equivalently, as given by the international definition, one unit of laccase activity is defined as the amount of enzyme solution that oxidizes a $\mu \mathrm{mol}$ of substrate, ABTS for PPO-I or DMP for PPO-II, per min in the test conditions (Barbosa et al., 1996).

Protein was measured by the method of Bradford (Bradford, 1976) using BSA as standard.

\section{Enzyme immobilization}

Chitosan was dissolved in $4 \%$ acetic acid, precipitated by adding $1 \mathrm{M} \mathrm{NaOH}$ up to $\mathrm{pH} 10.0$ and extensively washed with $30 \mathrm{mM}$ citrate phosphate buffer $\mathrm{pH} 6.0$ (referred below as buffer A). The precipitated obtained was dried at $40^{\circ} \mathrm{C}$ for $16 \mathrm{~h}$ and ground to a powder that passed through the 200 Mesh sieve. This constituted the immobilized enzyme support particles.
Laccase $(0.1 \mathrm{~g})$ was placed in contact with $1.0 \mathrm{~g}$ of support particles in $100 \mathrm{~mL}$ of buffer A. The suspension was kept at $4^{\circ} \mathrm{C}$ for $16 \mathrm{~h}$ under agitation $(120 \mathrm{rpm})$ and subsequently centrifuged at $7200 \mathrm{~g}$ at $4^{\circ} \mathrm{C}$ for $20 \mathrm{~min}$. The supernatant was reserved. The separated pellet deposit was resuspended in buffer A containing $1 \%$ glutaraldehyde $(\mathrm{v} / \mathrm{v})$. The suspension was stirred at $25^{\circ} \mathrm{C}$ for $90 \mathrm{~min}$ at $120 \mathrm{rpm}$ under vacuum and subsequently centrifuged at $7200 \mathrm{~g}$ at $25^{\circ} \mathrm{C}$ for 20 min. The supernatant was reserved. The enzymesupport complex was washed with small aliquots of buffer A containing $2 \mathrm{M} \mathrm{NaCl}$ (w/v) and buffer A alone until no protein was detected in the washings. The enzyme-support complex was maintained in buffer A under $4^{\circ} \mathrm{C}$ (D'Annibale et al., 1998).

\section{Definition of yields}

Adsorption yield (AY\%), binding yield (BY\%) and immobilization yield (IY\%) were defined as follows: $\mathrm{AY} \%=\left(\mathrm{U}_{\mathrm{ads}} / \mathrm{U}_{0}\right) \times 100 ; \mathrm{BY} \%=\left(\mathrm{U}_{\mathrm{bin}} / \mathrm{U}_{0}\right)$ $\mathrm{x} 100 ; \mathrm{IY} \%=\left(\mathrm{U}_{\mathrm{imb}} / \mathrm{U}_{0}\right) \times 100$. Where $\mathrm{U}_{0}$ is the number of enzymatic units present in the solution used for immobilization, $U_{a d s}$ are the adsorbed units evaluated as the difference between $\mathrm{U}_{0}$ and those remaining in the supernatant at the end of the adsorption procedure, $\mathrm{U}_{\text {bin }}$ are the binding units evaluated as the difference between $\mathrm{U}_{0}$ and those remaining in the supernatant at the end of the adsorption and cross-linking with glutaraldehyde procedures, and $\mathrm{U}_{\mathrm{imb}}$ are the immobilized units evaluated as the difference between $\mathrm{U}_{0}$ and those remaining in the supernatant at the end of the adsorption, cross-link with glutaraldehyde and wash with buffer $\mathrm{A}$ containing $\mathrm{NaCl}$ and wash with buffer A procedures.

\section{RESULTS AND DISCUSSION}

Chitosan, a deacetylated derivative of the biopolymer chitin, was selected as a support for laccase immobilization for the following reasons: (i) wide commercial availability and low costs; (ii) hydrophilic nature; (iii) polycationic nature. A first test with $1.0 \mathrm{~g}$ of chitosan was used (200 mesh) as support and $1.0 \mathrm{~g}$ of enzymatic extract of laccase dissolved in $100 \mathrm{~mL}$ of water, resulting in a concentration of $10 \mathrm{mg} / \mathrm{mL}$ of extract. Yield results are shown at Table 1. For comparison, two other tests were carried out (tests 2 and 3 ) with the same amount of support $(1.0 \mathrm{~g})$, but in these cases 
$0.1 \mathrm{~g}$ of enzymatic extract was dissolved in $100 \mathrm{~mL}$ of water, resulting in a concentration of 1.0 $\mathrm{mg} / \mathrm{mL}$ of extract. The arithmetic mean of the results obtained with tests 2 and 3are shown at Table 2.

A $4^{\text {th }}$ test was carried out with the same amount of support and concentration of enzymatic extract as previously described for tests 2 and 3 , but chitosan of different dimension (65 mesh) was used in this case. The results are shown at Table 3.

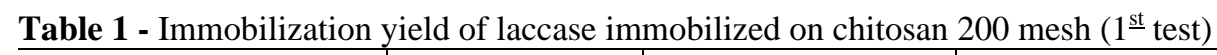

\begin{tabular}{|c|c|c|c|c|}
\hline $\begin{array}{c}\text { Laccase } \\
10 \mathrm{mg} / \mathrm{mL}\end{array}$ & $\begin{array}{c}\text { Initial activity } \\
\mu \mathrm{mol} / \mathrm{mL}\end{array}$ & $\underset{\%}{\text { AY }}$ & BY & $\begin{array}{l}\text { IY } \\
\text { \% }\end{array}$ \\
\hline $\begin{array}{c}\text { Pleurotus } \\
\text { ostreatus } \\
\text { (PPO-I) }\end{array}$ & 2.23 & 53.60 & 52.73 & 52.71 \\
\hline $\begin{array}{l}\text { Pleurotus } \\
\text { ostreatus } \\
\text { (PPO-II) }\end{array}$ & 3.34 & 16.22 & 12.94 & 12.83 \\
\hline $\begin{array}{l}\text { Aspergilus sp. } \\
\text { (PPO-I) }\end{array}$ & 15.36 & 5.12 & 1.34 & 0.83 \\
\hline $\begin{array}{l}\text { Aspergilus sp. } \\
\text { (PPO-II) }\end{array}$ & 25.96 & 10.98 & 6.13 & 5.85 \\
\hline $\begin{array}{l}\text { Botryosphaeri } \\
\text { (PPO-I) }\end{array}$ & 0.77 & 79.30 & 79.04 & 78.87 \\
\hline $\begin{array}{l}\text { Botryosphaeri } \\
\text { (PPO-II) }\end{array}$ & 0.07 & 75.49 & 71.23 & 69.71 \\
\hline
\end{tabular}

Table 2 - Average of immobilization yields for laccase immobilized on chitosan 200 mesh ( $2^{\text {nd }}$ and $3^{\text {th }}$ tests)

\begin{tabular}{|c|c|c|c|c|}
\hline $\begin{array}{c}\text { Laccase } \\
1 \mathrm{mg} / \mathrm{mL}\end{array}$ & $\begin{array}{c}\text { Initial activity } \\
\mu \mathrm{mol} / \mathrm{mL}\end{array}$ & AY\% & BY\% & IY\% \\
\hline $\begin{array}{c}\text { Pleurotus } \\
\text { ostreatus } \\
\text { (PPO-I) }\end{array}$ & 0.79 & 72.86 & 72.75 & 72.58 \\
\hline $\begin{array}{l}\text { Pleurotus } \\
\text { ostreatus } \\
\text { (PPO-II) }\end{array}$ & 1.33 & 67.63 & 66.95 & 66.83 \\
\hline $\begin{array}{c}\text { Aspergillus sp. } \\
\text { (PPO-I) }\end{array}$ & 2.58 & 44.11 & 41.67 & 41.47 \\
\hline $\begin{array}{l}\text { Aspergillus sp. } \\
\text { (PPO-II) }\end{array}$ & 4.52 & 31.99 & 27.63 & 27.37 \\
\hline $\begin{array}{l}\text { Botryosphaeria } \\
\text { (PPO-I) }\end{array}$ & 1.34 & 99.81 & 99.81 & 99.74 \\
\hline $\begin{array}{l}\text { Botryosphaeria } \\
\text { (PPO-II) }\end{array}$ & 0.44 & 99.32 & 99.21 & 99.17 \\
\hline
\end{tabular}


Table 3 - Immobilization yield of laccase immobilized on chitosan 65 mesh (4 $4^{\text {th }}$ test)

\begin{tabular}{|c|c|c|c|c|}
\hline $\begin{array}{c}\text { Laccase } \\
1 \mathrm{mg} / \mathrm{mL}\end{array}$ & $\begin{array}{c}\text { Initial activity } \\
\mu \mathrm{mol} / \mathrm{mL}\end{array}$ & AY\% & BY\% & IY\% \\
\hline $\begin{array}{c}\text { Pleurotus } \\
\text { ostreatus } \\
\text { (PPO-I) }\end{array}$ & 0.51 & 56.87 & 56.23 & 46.03 \\
\hline $\begin{array}{l}\text { Pleurotus } \\
\text { ostreatus } \\
\text { (PPO-II) }\end{array}$ & 0.16 & 46.95 & 43.78 & 41.72 \\
\hline $\begin{array}{l}\text { Aspergillus sp. } \\
\text { (PPO-I) }\end{array}$ & 1.58 & 35.28 & 26.68 & 26.01 \\
\hline $\begin{array}{l}\text { Aspergillus sp. } \\
\quad \text { (PPO-II) }\end{array}$ & 2.42 & 49.38 & 47.01 & 46.81 \\
\hline $\begin{array}{l}\text { Botryosphaeria } \\
\text { (PPO-I) }\end{array}$ & 1.07 & 99.39 & 99.39 & 99.34 \\
\hline $\begin{array}{l}\text { Botryosphaeria } \\
\text { (PPO-II) }\end{array}$ & 0.12 & 99.68 & 99.45 & 98.62 \\
\hline
\end{tabular}

\section{1st test Average of 2nd and 3rd tests}

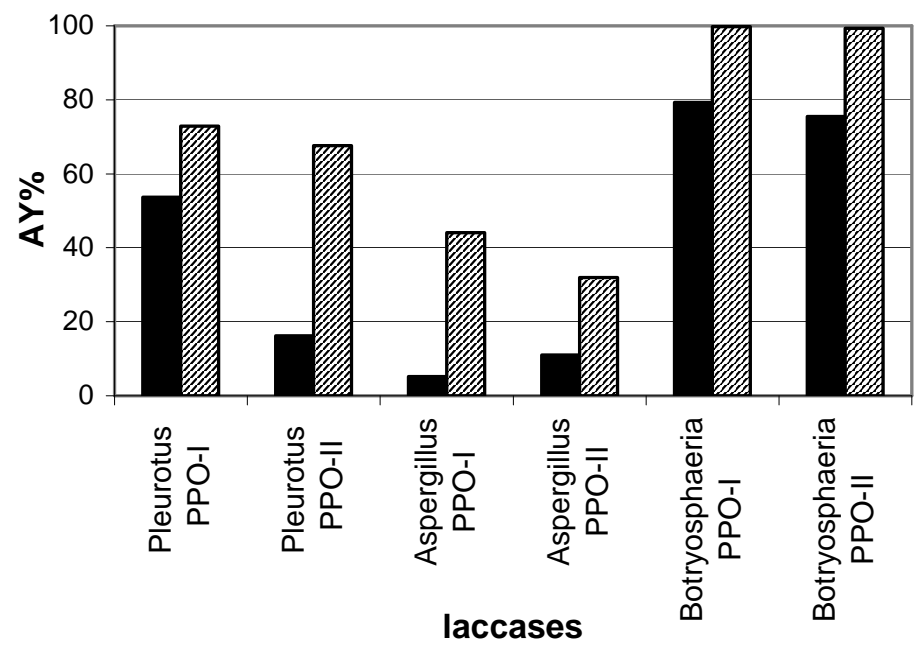

Figure 1 - Adsorption yields (test 1 and average of tests 2 and 3).

As can be seen in Tables 1, 2 and 3, for all the types of tested laccases, the highest immobilized enzyme activities were observed when a concentration of $1 \mathrm{mg} / \mathrm{mL}$ of laccase enzymatic extract was used with $1 \mathrm{~g}$ of the chitosan support (200 mesh). Laccase from Botryosphaeria sp. gave the best yields. Graphs were drawn for a better visualization of these results. Figure 1 compares the adsorption yields obtained with different concentrations of enzymatic extract of laccase at the immobilization tests (test 1 and average of the tests 2 and 3 ).

Figure 2 compares the binding yields obtained for test 1 and the average of tests 2 and 3, which had different concentrations of the laccase enzymatic extract. Figure 3 compares the immobilization 
yields (test 1 and average of the tests 2 and 3 ) with different concentrations of the enzymatic extract of laccase.

Comparing Tables 2 and 3 data, for which the difference was the dimension of the chitosan support particles, it is observed that for the larger particles (65 mesh, Table 4) smaller immobilization yields were more commonly found. This could be explained by the saturation of the superficial area of the chitosan particles, after the stage of adsorption, this area being proportionally smaller for the larger particles.

\section{1st test 0 Average of 2 nd and 3rd tests}

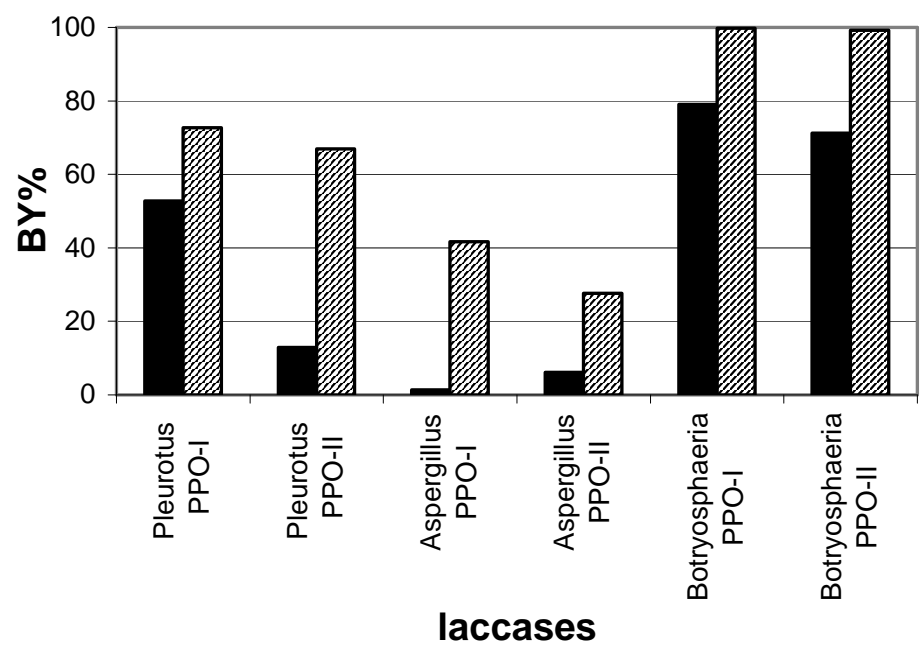

Figure 2 - Binding yields obtained for test 1 and the average of tests 2 and 3.

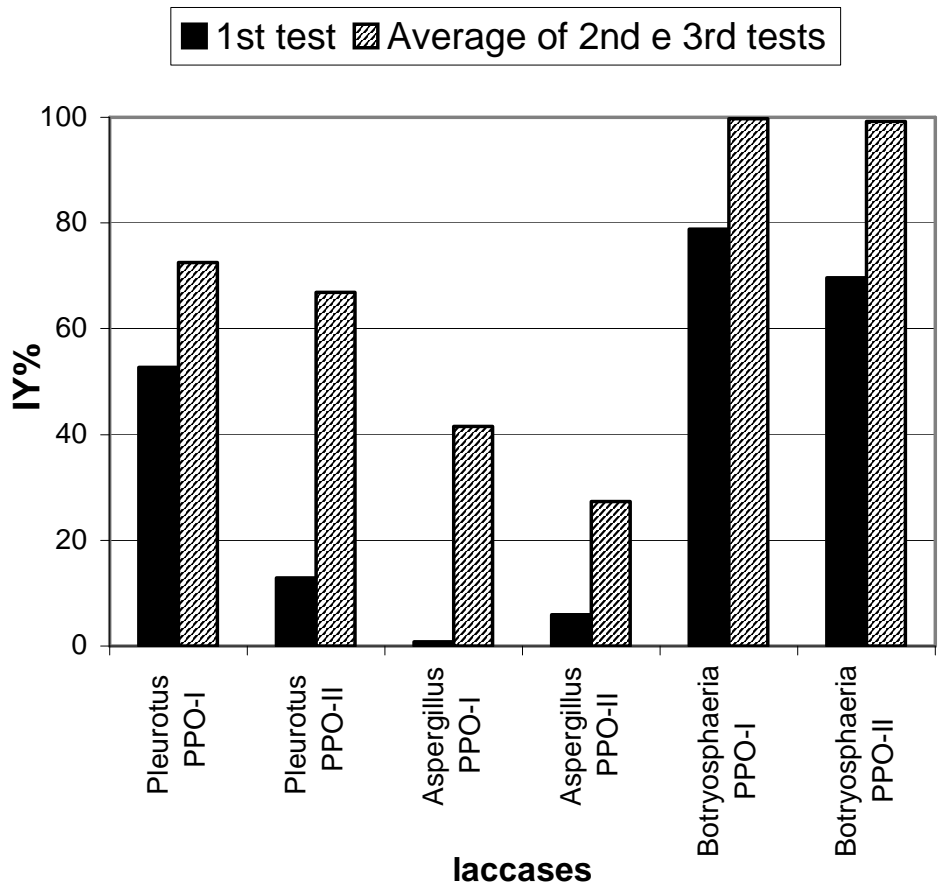

Figure 3 - Immobilization yields (test 1 and average of tests 2 and 3). 


\section{RESUMO}

A enzima fenol-oxidase lacase obtida da cultura de dos fungos Pleurotus ostreatus e Botryosphaeria $s p$, e de origem comercial, obtida de Aspergillus sp. foi imobilizada em quitosana, grau farmacêutico, por adsorção seguida de ligação cruzada. Diferentes condições de imobilização com relação à granulometria do suporte e à quantidade de extrato enzimático de lacase utilizado foram testadas, visando-se obter elevadas atividades enzimáticas com a enzima imobilizada. Dois diferentes substratos foram utilizados para a determinação da atividade enzimática, ABTS e DMP. A maior atividade foi obtida com $1,0 \mathrm{mg} / \mathrm{mL}$ do extrato enzimático de lacase de Botryosphaeria $s p$. para 1,0g de suporte (200 mesh). Estas enzimas imobilizadas se destinam à melhoria de vinhos brancos, via degradação de compostos fenólicos indesejados.

\section{REFERENCES}

Barbosa, A. M.; Dekker, R. F. H.; Kurtböke, I. and Hardy, G. (1996), Veratryl alcohol as inducer of laccase by ascomycete, Botryosphaeria sp, when screened on polymeric dye Poly R-478. Lett. Appl. Microbiol., 23, 93-96.

Bradford, M. M. A. (1976), Rapid and sensitive method for the quantification of microgram quantities of protein utilizing the principle of protein dye binding; Analytical Biochemistry, 72, 248-254.

D’Annibale, A.; Stazi, S. R.; Vinciguerra, V.; Di Mattia, E. and Sermanni, G. G. (1999), Characterization of immobilized laccase from Lentinula edodes and its use in olive mill wastewater treatment; Process Biochemistry, 34, 697-706.

Gianfreda, L.; Xu, F. and Bollag, J. M. (1999), A useful group of oxidoreductive enzymes. Bioremediation Journal, 3 : (1), 1-26.
Jolivalt, C.; Brenon, S.; Caminade, C.; Mougin, C. and Pontié, M. (2000), Immobilization of laccase from Trametes versicolor on a modified PVDF microfiltration membrane: Characterization of the grafted support and application in removing a phenylurea pesticide in wastewater. Journal of Membrane Science, 180, 103-113.

Minussi, R. C.; Pastore, G. M. and Duran, N. (2002), Potential applications of laccase in the food industry. Trends in Food Science and Technology, 13, 205-216.

Received: September 29, 2004; Revised: February 25, 2005; Accepted: March 25, 2005. 